\title{
The use of MDT in the three Western Regions of Nepal
}

\author{
P G KALTHOFF \\ Olper Str 56, 5275 Bergneustadt, Federal Republic of Germany
}

\section{The Leprosy Control Programme in West Nepal}

The Leprosy Control Programme (LCP) covers 21 districts in the three western regions of Nepal, and provides treatment for more than 10,000 leprosy patients in about 200 treatment units of the Basic Health Service, and several hospitals/ referral centres. PMWs work at various levels, visiting health posts and running clinics on a pre-fixed date. The number of clinic days per month varies according to the number of patients per unit, but in most of the treatment places there are less than 25 registered patients, and those places are attended bi-monthly.

The majority of treatment units are not easily accessible, and most of the travelling has to be done on foot, which considerably limits the supervisory assistance given to the paramedical staff and consequently the PWM must be able to deal with the entire care of leprosy patients, including diagnosis, dealing with complications, and release from control.

\section{Introduction of MDT}

The WHO recommended regime of MDT was introduced to the LCP in Nepal in April 1982, following the second National Workshop on Leprosy Control in November 1981 in Kathmandu. Guidelines for the country were defined at that time.

In the three western regions of Nepal, MDT is now used in eight districts and in three specialized referral centres. (General information on the number of patients treated in the programme in West Nepal, as well as those who have been or are on MDT, is given in Table 1.)

The introduction of MDT to the operational pattern of the LCP was assisted by the following measures:

A standing order was designed (in English and the national language, Nepali), 
which gave the PWM all the necessary details for handling MDT on their own.

The necessary structured training was given to paramedicals.

The recording and reporting system of the programme was adjusted to MDT and necessary additions were made.

The monthly supply of medicine was packed in convenient plastic bags (this assists the pattern that one dosage of rifampicin and $300 \mathrm{mg}$ clofazimine can be taken unsupervised).

A leaflet was designed for the patient giving him basic information on MDT and instructions on how to take the medicine.

A poster was produced to assist the health education campaign.

\section{Area of evaluation}

To evaluate the operational set-up of MDT, four studies were performed, one in a referral centre and three in the field.

Green Pastures Leprosy Hospital ${ }^{1}$, where MDT was started first (in April 1982), is an old established place with about 1000 outpatients and acts as a referral centre. Outpatients are routinely seen by the PWM staff only. Seven months later a study was done, investigating the functioning of the operational set-up of those patients coming from one district only (Kaski District, surrounding the hospital).

In the same district, Kaski, leprosy patients are also treated in 12 health posts according to the described operational set-up of the LCP. One year after MDT was introduced into those health posts the operational set-up was investigated as well.

In the Western Terai, MDT was started in the Banke District at the same time as in Kaski. Many patients are treated there. The operational set-up in the health

Table 1. Patients on multidrug therapy

\begin{tabular}{|c|c|c|c|c|c|c|c|c|c|}
\hline & \multicolumn{3}{|c|}{ Field } & \multicolumn{3}{|c|}{ Referral centre } & \multicolumn{3}{|c|}{ Total } \\
\hline & Multi & Pauci & Total & Multi & Pauci & Total & Multi & Pauci & Total \\
\hline $\begin{array}{l}\text { No. of patients } \\
\text { on MDT }\end{array}$ & 383 & 566 & 949 & 575 & 257 & 832 & 958 & 823 & 1781 \\
\hline $\begin{array}{l}\text { Patients already } \\
\text { released from MDT }\end{array}$ & - & 306 & & - & 268 & & - & 574 & \\
\hline
\end{tabular}

Total No. of patients: field, 5863; referral centre, 4740. Total 10603

Twenty-one per cent of patients are receiving or have received MDT. 
post of the district capital, Nepalganj, treating 456 patients, was also investigated one year after MDT was introduced.

In addition to this, the study in the Banke District has been extended to four more health posts to give additional information beyond the health post in the district centre, Nepalganj.

The whole study was concluded in mid-1983.

\section{Results}

\section{NUMBER OF PATIENTS ON MDT}

About one year after MDT was introduced, about $80 \%$ of all registered patients were on MDT (Table 2).

\section{OPERATIONAL SET-UP}

Detailed measures in relation to the operational set-up of MDT as described above were only done after MDT had already been started in the Green Pastures Leprosy Hospital. For this reason, this hospital basically continued handling the patients according to the previous regime. Most of the faults found were, therefore, related to lack of clear operational instructions.

Clinical examination performed at the start of MDT (Table 3)

In both field areas, the Kaski District as well as the Nepalganj health post in the

Table 2. General information

\begin{tabular}{|c|c|c|c|c|c|}
\hline \multirow[b]{2}{*}{ Treatment unit } & \multirow{2}{*}{$\begin{array}{l}\text { No. of } \\
\text { patients } \\
\text { registered }\end{array}$} & \multicolumn{3}{|c|}{ No. of patients on MDT } & \multirow{2}{*}{$\begin{array}{c}\% \text { of } \\
\text { patients } \\
\text { on MDT }\end{array}$} \\
\hline & & Multi & Pauci & Total & \\
\hline \multicolumn{6}{|c|}{$\begin{array}{l}\text { GP referral centre } \\
\text { patients from Kaski }\end{array}$} \\
\hline District only & 350 & 129 & 126 & 255 & (73) \\
\hline \multicolumn{6}{|l|}{ Kaski District } \\
\hline $12 \mathrm{HP}$ & 155 & 35 & 89 & 124 & $(80)$ \\
\hline \multicolumn{6}{|l|}{ Banke District } \\
\hline Nepalganj HP & 456 & 135 & 242 & 377 & $(82)$ \\
\hline \multicolumn{6}{|l|}{ Banke District } \\
\hline $4 \mathrm{HP}$ & 178 & 45 & 113 & 158 & (89) \\
\hline
\end{tabular}


Table 3. Operational set-up. Examination performed at the start of MDT

\begin{tabular}{llclll}
\hline & \multicolumn{3}{c}{ Clinical examinations } & $\begin{array}{l}\text { Smears } \\
\text { taken }\end{array}$ \\
Treatment unit & No. & $(\%)$ & \multicolumn{2}{l}{ No. } & $(\%)$ \\
\hline $\begin{array}{c}\text { Kaski District only } \\
\text { GP referral centre }\end{array}$ & $?$ & $?$ & 133 & $(52)$ \\
$\begin{array}{c}\text { Kaski District } \\
\text { 12 HP }\end{array}$ & 123 & $(99 \cdot 2)$ & 119 & $(96)$ \\
$\begin{array}{c}\text { Banke District } \\
\text { Nepalganj HP }\end{array}$ & 367 & $(97 \cdot 3)$ & $326^{*}$ & $(86)$ \\
\hline
\end{tabular}

* Twenty-six smears which were taken later or earlier are not included.

Banke District, almost all patients were examined at the beginning of MDT, while those figures were not evaluated at the Green Pastures Leprosy Hospital.

\section{Bacteriological examination at the beginning of MDT (Table 3)}

As far as smear-taking is concerned, it becomes particularly obvious that the lack of clear instructions when MDT was introduced to the Green Pastures Leprosy Hospital resulted in an insufficient number of smears being taken at the beginning of MDT (but it must also be stated that a number of smears had been taken in recent months before the patient was put on MDT). In both field areas, the number of smears taken is sufficiently high, although in the Banke district not all were taken exactly at the right date.

Table 4. Operational set-up. Smear results recorded in patients' records at beginning of MDT (including some smears taken later or earlier)

\begin{tabular}{|c|c|c|c|}
\hline \multirow[b]{2}{*}{ Treatment unit } & \multirow[b]{2}{*}{ No. of smears taken } & \multicolumn{2}{|c|}{ Smears not recordec } \\
\hline & & No. & $(\%)$ \\
\hline \multicolumn{4}{|l|}{ Banke District } \\
\hline Nepalganj HP & 345 & 40 & $(11 \cdot 6)$ \\
\hline \multicolumn{4}{|l|}{ Banke District } \\
\hline 4 other HP & 157 & 50 & $(32)$ \\
\hline \multicolumn{4}{|l|}{ Kaski District } \\
\hline $12 \mathrm{HP}$ & 119 & 9 & $(7 \cdot 6)$ \\
\hline
\end{tabular}


Table 5. Operational set-up. Monthly unrecorded smear results outstanding

\begin{tabular}{lccccc}
\hline & $1 / 12$ & $2 / 12$ & $4 / 12$ & $5-6 / 12$ & $11 / 12$ \\
\hline $\begin{array}{l}1 \text { of the 4 HP Banke District } \\
\text { Kaski District } \\
12 \mathrm{HP}\end{array}$ & - & - & 1 & 4 & $10(!)$ \\
\hline
\end{tabular}
12.

A smear result should be reported after 2/12, but not after $4 /$

\section{Recording of smears performed (Tables 4 and 5)}

Smears are taken in the field, fixed and despatched to the referral centre concerned via the control office or, in some cases, to a laboratory of the Basic Health Services. The reports from referral centres are communicated via the office to the centre of each district; from there the PMW takes them to the different health posts.

This administrative line is rather complicated and liable to failures. Evaluating the results of Kaski district first, $7 \cdot 6 \%$ of smears were outstanding, but only for 1 to 2 months (Table 5). Concerning the 'smear chain' described above, this is normal, and so it can be said that in Kaski District no smear result was lost.

This is particularly different in the four other health posts investigated in the Banke District. A detailed study of one of these health posts revealed that the majority of smears are already 11 months late! On investigation, it became obvious that the fault is mainly in the field: smears are despatched too late to the office; smear results are kept in the district centre only, and are not taken to the individual health posts; and there was a decrease in the work performance since the introduction of MDT (compare Nepalganj health post with the four others in Banke, Table 4).

Evaluating some factors of the operational set-up emphasizes that:

The operational set-up must be clear before MDT is started and detailed instructions must be given to the PMW staff to enable them to handle their work with confidence. This applies equally to the field and to hospitals, even if more expert personnel is available in the latter.

After adequate training, the staff need to be sufficiently introduced to their duties and periodically supervised in areas where they work on their own.

QUALITY OF CLINICAL WORK

Clinical examination activity or inactivity (Table 6) and recognition of complications (Table 7)

The result of the field-work in both districts shows great uncertainty of the PMWs 
Table 6. Quality of clinical work. Clinical examinations: patients active or inactive at the start of MDT.

\begin{tabular}{|c|c|c|c|}
\hline Multibacillary & Active & Inactive & $\begin{array}{l}\text { No record of } \\
\text { or records } \\
\text { disagree } \\
(\%)\end{array}$ \\
\hline Kaski & 11 & 4 & $20(57)$ \\
\hline Nepalganj HP & 47 & 43 & $42(32)$ \\
\hline \multicolumn{4}{|l|}{ Paucibacillary } \\
\hline Kaski & - & 41 & $48(54)$ \\
\hline Nepalganj HP & 57 & 171 & $7(3)$ \\
\hline
\end{tabular}

concerning the decision of whether a patient is active or inactive. Examination of records reveals that active symptoms are listed, but the patient in fact is considered as inactive; or records are incomplete on this issue. Frequently it is also difficult for the PMWs to make decisions because previous records are incomplete.

In a similar way, complications are insufficiently recognized and recorded. It is unlikely that the number of reactions is below 5\% after MDT is introduced.

Drug side-effects are mostly not recorded at all.

The uncertainty in reaching proper conclusions after clinical examinations and not recognizing complications in time applies also to good paramedical staff. The findings, on the one hand, emphasize the need for sufficient training, particularly with clinical practice and constant re-training and, on the other, for a recording system which reminds the PMW to follow the proper examination pattern in order to come to the right conclusions.

We have recently developed a new patient recording system which follows far more the pattern of ticking-off certain symptoms. It leads automatically also to those in relation to complications and, in cases where they are present, the PMW is asked to fill in a special Complications Form. In this way we hope to overcome such weaknesses revealed in the current study.

FOLLOW UP

Regularity of patients before and after starting MDT (Table 8)

It is interesting to see that, in fact, the regularity under MDT has only gone up in the health posts of the Kaski District and of the Green Pastures Leprosy Hospital. There was a drop at the Nepalganj health post, and particularly at the other four 
Table 7. Quality of clinical work. Complications recorded.

\begin{tabular}{lc} 
& \multicolumn{1}{c}{ Reactions } \\
\cline { 2 - 2 } & No. $(\%)$ \\
\cline { 2 - 2 } Green Pastures & $6(2 \cdot 4)$ \\
Kaski & $4(3 \cdot 2)$ \\
Nepalganj & $19(5)$ \\
\hline
\end{tabular}

Drug side-effects-records are too unclear to draw conclusions.

Table 8. Regularity. Definition of MDT regularity: Number of once-monthly doses given and oncemonthly doses possible (\%)

\begin{tabular}{|c|c|c|c|c|}
\hline \multirow[b]{2}{*}{ Treatment unit } & \multicolumn{2}{|c|}{ Regular on MDT } & \multicolumn{2}{|c|}{$\begin{array}{c}\text { Regular before } \\
\text { MDT }\end{array}$} \\
\hline & No. & $(\%)$ & No. & $(\%)$ \\
\hline Green Pastures & 192 & 89 & 327 & 83 \\
\hline \multicolumn{5}{|l|}{ Kaski District } \\
\hline $12 \mathrm{HP}$ & 102 & 85 & 119 & 74 \\
\hline Nepalganj & 255 & 73 & 321 & 84 \\
\hline \multicolumn{5}{|l|}{ Banke District } \\
\hline $4 \mathrm{HP}$ & 104 & 66 & $127 *$ & 79 \\
\hline
\end{tabular}

health posts of the same district, Banke. In fact for some months the work performance decreased after MDT had been introduced.

The routine system introduced to follow up late patients is: a registered letter is written after the patient has failed to attend a clinic day; and if the patient fails to attend again, a home visit is done.

Other studies in the programme have shown that there is a response to letters of about $30 \%$, while there is even less to home visits. Home visits are popular amongst the PMW staff because they get extra travelling allowance for these, while letters are just additional work. The latest supervision visit revealed that letters had not been sent for 8 months in the Banke District. Home visits had to be 
Table 9. Regularity. Compliance.

Clofazimine skin discolouration

\begin{tabular}{lcc}
\hline & & Absent \\
& Present & No. (\%) \\
\hline Green Pastures & 84 & $2(2 \cdot 4)$ \\
\hline
\end{tabular}

stopped because of a budget shortage. The effect of these can be questioned anyway. The situation needs careful investigation to make sure that the regularity of attendance will reach an acceptable standard again.

\section{Compliance (Table 9)}

This study was done in Green Pastures Leprosy Hospital only, but it showed that almost all patients put on clofazimine were, in fact, taking the medicine. This was also confirmed by the field staff of the Kaski District.

\section{Frequency of once-monthly dosage missed (Table 10)}

Clinic days in health posts attended by the staff of the LCP are fixed, and in many places are bi-monthly only. If the patient comes on the wrong day, he will get antileprosy treatment but no rifampicin. But the patient must take his minimum dosage of rifampicin. If they miss it in certain months, this time needs to be added to their whole treatment period. For example, if a patient on paucibacillary treatment misses it for 4 months, his whole treatment period will be 10 months.

The evaluation shows that in those four health posts in the Banke district less than $50 \%$ of the patients never missed a clinic day and received all their monthly doses of rifampicin continuously. More worrying are those patients who missed more than 4 times their monthly dosage (up to $31 \%$ ).

Table 10. Frequency of once monthly dosage missed

\begin{tabular}{lcccccccc}
\hline & None & Up to 3/12 & $4 / 12-6 / 12$ & $\begin{array}{c}\text { More than } \\
6 / 12\end{array}$ \\
\hline $\begin{array}{l}\text { Banke District } \\
\quad \text { 4 HP }\end{array}$ & No & $(\%)$ & No & $(\%)$ & No & $(\%)$ & No & $(\%)$ \\
$\begin{array}{l}\text { Multibacillary } \\
\text { Paucibacillary }\end{array}$ & 12 & $(27)$ & 17 & $(38)$ & 8 & $(18)$ & 8 & $(18)$ \\
$\begin{array}{l}\text { Total } \\
\text { Total }\end{array}$ & 69 & $(44)$ & 40 & $(20)$ & 12 & $(11)$ & 21 & $(19)$ \\
\hline
\end{tabular}




\section{Conclusions}

It has been proved that, even under very difficult field conditions like those in Nepal, MDT can be introduced in the field if there are detailed instructions available for the PMW, together with sufficient training. In addition, supervision needs to be done, particularly at the beginning to introduce the new system properly, as well as periodically afterwards to make sure the system is followed. We are hoping that the new patient recording system will help to improve the standard further, and particularly to allow us precise evaluation of the programme in the future.

\section{Reference}

${ }^{1}$ Birch, MC. Leprosy treatment in Nepal with multidrug regimens. Lepr Rev 1984; 55: 255-64. 